\title{
Effect of hyperimmunized egg yolk on maternal immunity of Newcastle disease vaccine in broiler chicks
}

\author{
A.Z. Al-Zubeedy and M.Y. Al-Attar \\ Department of Microbiology, College of Veterinary Medicine, Mosul University, Mosul, Iraq
}

\begin{abstract}
Hyperimmunized egg yolk (HIY) was produced in two layer hens by four successive immunization with live attenuated Newcastle disease vaccine (NDV) by seven days intervals for each vaccination process. Fifty broiler chicks were used for treatment with hyperimmunized yolk. They were divided into five groups. The first group was treated at 14th days of age by orally and intramuscular injection (five chicken for each route). The second group was boostered with (HIY) after 7 days of first dose at14 days of age. The third group as that of the first group but treated at $21^{\text {st }}$ day of age. The fourth group was treated at $21^{\text {st }}$ days and boostered after 7 days. The fifth group was ten chicks remain without any treatment used as control comparison of all groups. Immune response was measured using HI technique.The results showed that the group of $14^{\text {th }}$ day of age with booster dose gave high antibody titer by intramuscular injection (second group).
\end{abstract}

Keywords: Newcastle disease; Hyperimmunized yolk; Broiler; HI test; maternal immunity. Available online at http://www.vetmedmosul.org/ijvs

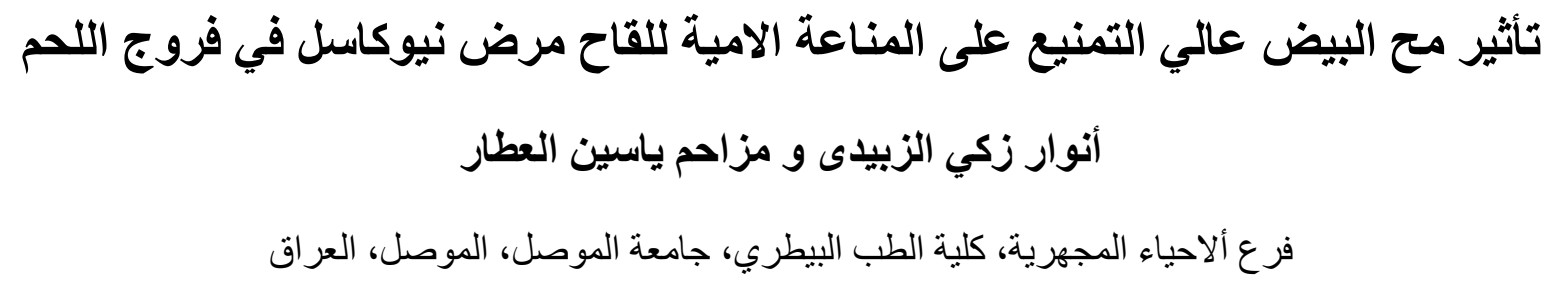

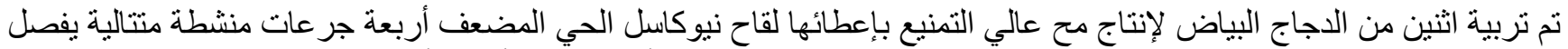

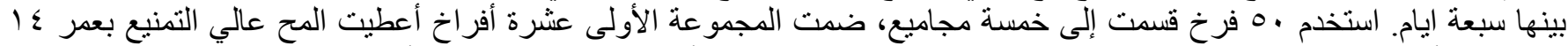

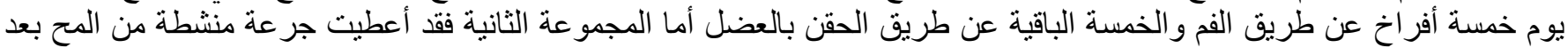

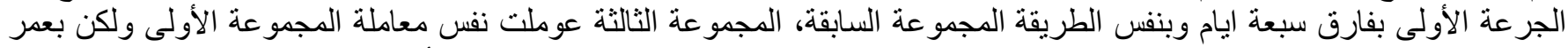

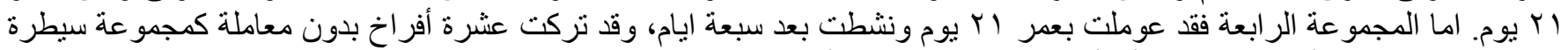

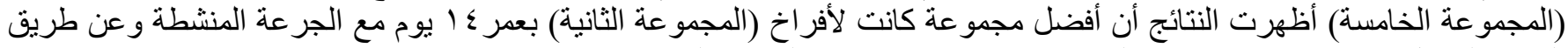

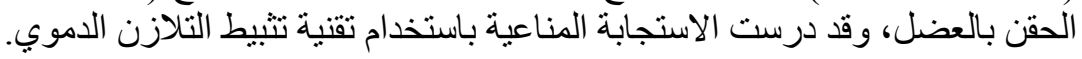

\section{Introduction}

The immune system of poultry is a complex network of different cell types and soluble factors that give effective response to pathogenic challenges. The function of the immune system is directly associated with poultry health (1). Among the infectious diseases, ND is a deadly viral disease of poultry due to its high contagiousness and rapid spreading character. Vaccination for protecting chicken from ND is routinely practiced throughout the world, but the vaccination is ineffective with the high titer of maternal antibodies $(2,3)$. In birds the maternal antibodies in the egg is manifested by three classes of antibodies in chicken namely $\operatorname{IgY}, \operatorname{IgA}$ and $\operatorname{IgM}(4-6), \operatorname{IgY}$ is present in the egg yolk whereas IgA and IgM are present in the egg white as a result of mucosal secretion in the oviduct, the transfer of IgY from the dam to her offspring takes place in a two step process in the first step $\operatorname{IgY}$ is taken up into the egg yolk by IgY receptors on the ovarian follicle from the dam's blood through the granulosa cells in the second step $\operatorname{IgY}$ is 
transferred from the egg yolk to the offspring via the embryonic circulation $(4,6-8)$. This type of immunoglobulin is act as passive immunity because these antibodies are derived from the dam and protect the offspring from various infectious disease (9). Chicken can provide a convenient and economic source of immunoglobulin in their egg yolk, the efficiency of egg yolk immunoglobulin (IgY) has been assessed for therapeutic application by passive immunization therapy for prevention or control of different infections (10) Many reports were studied the prophylactic effect of egg yolk IgY and its success in the prevention of different pathogens as Helicobacter pylori (11), enterotoxicogenic, E. Coli, Streptococcus mutans, Salmonellosis, Campylobacterosis, mixed bacterial infections, Staphylococcus with Pseudomonas and viral diseases as Infectious bursal disease, Newcastle disease, Rota virus, (12-16).

This paper describes the production of hyperimmunized egg yolk (HIY) in layer chicken and the purification of egg yolk in order to study its effect on maternal derived antibody titers of NDV.

\section{Materials and methods}

\section{Production of hyperimmunized yolk}

Two layer chickens (22) weeks old were vaccinated with one vaccinal lasota strain of NDV (Lohmann company) dose of $\left(10^{7} \mathrm{EID}_{50} / 0.1 \mathrm{ml}\right)$ orally for four times with seven days interval between each vaccination.

\section{Collection of egg samples}

Eggs were collected once before ND vaccination and other four groups of eggs were collected after one week after each immunization then were stored at $4^{\circ} \mathrm{C}$ until further use.

\section{Separation of egg yolk}

Egg yolk was taken out of the egg shell, placed in a sterile container and mixed with the same volume of sterile phosphate buffer saline (PBS) with shaking. The emulsion was centrifuged at $1500 \mathrm{rpm} / 20 \mathrm{~min}$, The mixture was separated into 2 layers, the clear supernatant fluid containing the $\mathrm{IgY}$ was collected and stored at $-20^{\circ} \mathrm{C}$ until analysis $(17,18)$.

\section{Experimental chicks}

Fifty-one-day- broiler chicks were housed in animal house of veterinary medicine college and kept for ad libitum containing no antibiotics. All birds were not vaccinated,ten were chicks used as control group without any treatment and 40 chicks were divided into four groups
First group: Ten chicks on $14^{\text {th }}$ days old were given $1 \mathrm{ml}$ of IgY containing fluid, by oral and I/M injection routes as a single dose, five chicks for each route of administration).

Second group: Ten chicks on $14^{\text {th }}$ days old were given $1 \mathrm{ml}$ of IgY containing fluid followed by boostering dose after one week at the routes and number of birds.

Third group: Ten chicks on $21^{\text {st }}$ days old were divided into two subgroups 5 chick were given IgY containing fluid $1 \mathrm{ml}$ by oral and I/M injection as single dose.

Fourth group: Ten chicks on $21^{\text {st }}$ days old were given $1 \mathrm{ml}$ of $\operatorname{IgY}$ containing fluid with boostering dose after one week from the first dose by oral and $1 / \mathrm{M}$ routes (5birds for each route).

Fifth group: Ten chicks remain without any treatment and regarded as negative control.

\section{Collection of serum samples}

Blood samples were collected from all experimental groups by heart puncture then sera were separated by centrifugation at 2000rpm for ten minutes and were stored at $-20^{\circ} \mathrm{C}$ until further use.

\section{HI test}

Antibody titer against Newcastle disease virus (NDV) in serum and yolk was determined by (HI) technique depending on (4HA) units (17).

\section{Statistical analysis}

Data of all experiments were expressed as mean $\pm \mathrm{SE}$ data were compared by one way and tow way analysis of variance. Significant differenced determined by holm-sidak and Duncan's multiple range test. All statistical analysis performed by sigma stat (Jandel scientific software v3.1) $(\mathrm{P}<0.05)$ was considered as statistically significant.

\section{Results}

\section{Newcastle disease antibody titres in laying hens}

The results of the present study revealed that the antibody titre of hyperimmunized yolk were different significantly $(\mathrm{P}<0.05)$ in the collected eggs. The higher HI titer against NDV was 4.625 when layer chickens were vaccinated with live attenuated Newcastle disease vaccine with three booster doses, (Table 1).

\section{Newcastle disease antibody titre in broiler chicks}

The serum antibody titres of control group (fifth group) show the high maternal derived antibody titer through the two weeks only $(5.250,4.375,3.625)$ then decline gradually to reach 0.833 at five weeks of age, (Table 2). 
Table (1): Mean \pm SE of HI titre in egg yolk after successive NDVvaccination of layer hens.

\begin{tabular}{lcc}
\hline $\begin{array}{l}\text { Numbers of vaccination to } \\
\text { layer chickens }\end{array}$ & $\begin{array}{c}\text { No.of } \\
\text { examined } \\
\text { eggs }\end{array}$ & $\begin{array}{c}\text { Mean } \pm \mathrm{SE} \\
\text { HI titre of } \\
\text { egg yolk }\end{array}$ \\
\hline One vaccine only & 5 & $2.800 \pm$ \\
& 8 & $\begin{array}{c}3.200 \mathrm{~A}^{*} \\
\text { vaccine+one booster dose }\end{array}$ \\
vaccine +two booster doses & 8 & $\begin{array}{c}0.267 \mathrm{~A} \\
4.125 \pm \\
\text { vaccine +three booster doses }\end{array}$ \\
Control & 8 & $0.295 \mathrm{~B}$ \\
& & $4.625 \pm$ \\
& 8 & $2.183 \mathrm{~B}$ \\
& & $0.263 \mathrm{~A}$ \\
\hline
\end{tabular}

*A-B values within a column following by different letters are significantly different $(\mathrm{P}<0.05)$.

Table 2: Mean \pm SE HI maternal antibody titres of control group (fifth group) chicks.

\begin{tabular}{cc}
\hline Age of birds & Mean \pm SE HI serum titre \\
\hline One Day & $5.250 \pm 1.282 \mathrm{a}^{*}$ \\
7 Days & $4.375 \pm 0.744 \mathrm{ab}$ \\
14 Days & $3.625 \pm 1.88 \mathrm{bc}$ \\
21 Days & $3.00 \pm 0.926 \mathrm{~cd}$ \\
28 Days & $2.2 \pm 0.447 \mathrm{de}$ \\
35 Days & $0.833 \pm 0.753 \mathrm{e}$ \\
\hline
\end{tabular}

*Different letters in the column revealed significant differentces $(\mathrm{P}<0.05)$.

The results of antibody titres of experimentaly treated chicks with hyperimmunized yolk show significantly higher antibody titres with $\mathrm{I} / \mathrm{M}$ injection compared with those treated with oral route in all groups. The higher titre was 5.8 recorded in the second group (chicks treated in two weeks with booster dose) and also give higher antibody titres of 4.4 by oral route. These titres were higher than those reported in the remaining groups ( 3 and 4 ) and in both oral and $\mathrm{I} / \mathrm{M}$ injection routes (Table 3).

\section{Discussion}

The present study show that antibodies as $\operatorname{IgY}$ transferred to egg and then given to the newly hatched broiler chicks (4) the hyperimmunized yolk of the layer chicken that vaccinated with live attenuated Newcastle disease vaccine show high yolk antibody titre that increased with repeated immunization of layer hens and this result were coencides with the results of $(12,14,17)$ who revealed that repeated immunization of layer hens with live attenuated vaccine give good yolk antibody titer. The other fact that was reaffirmed in the present study the chicken egg yolk was recognized as the antibody source and the important of using egg yolk immunoglobulin IgY has been assessed for therapeutic application by passive immunization when the chicks treated with hyperimmunized yolk, the higher ratios were seen in $2^{\text {nd }}$ group were treated in two week of age with yolk and boostering after one week with it and this agreed with (10) who revealed that multiple treatment with egg yolk increased the antibody titer and also (9) who consider egg yolk containing high level of antibodies that give protection of $80 \%$ of birds against NDV and this fact can be easily applicated in the other infectious diseases of poultry. The current study also revealed that intramuscular injection route is the best method for immunization this result were in line with that of $(9,18-21)$ this could be explained by that oral administrated of egg yolk may be affected by acid denaturation in the proventiculus and gizzard and by proteases, however a fraction of the administrated dose retains some immunological activity against gastrointestinal tract.

In conclusion $\operatorname{IgY}$ administration by $\mathrm{I} / \mathrm{M}$ give great future opportunities for prophylactic strategies to increase and maintain protective level of immunity against NDV and if this approach works well it may help to justify commercial application of these antibodies.

Table 3: Mean \pm SE serum antibody titres of treated chicks with IgY containing fluid in different groups.

\begin{tabular}{lccc}
\hline \multirow{2}{*}{ Type of group } & \multicolumn{3}{c}{ Mean \pm SE HI serum antibody titre } \\
\cline { 2 - 4 } & Oral & $\begin{array}{c}1 / \mathrm{M} \\
\text { injection }\end{array}$ & $\begin{array}{c}\text { Fifth group } \\
\text { (control) }\end{array}$ \\
\hline \multirow{2}{*}{ First } & $3.8 \pm \mathrm{A}^{*}$ & $4.60 \pm \mathrm{A}$ & $3.625 \pm \mathrm{A}$ \\
& $0.270 \mathrm{a}^{* *}$ & $0.270 \mathrm{~b}$ & $1.88 \mathrm{a}$ \\
Second & $4.4 \pm \mathrm{A}$ & $5.8 \pm \mathrm{B}$ & $3.00 \pm \mathrm{A}$ \\
& $0.270 \mathrm{a}$ & $0.270 \mathrm{~b}$ & $0.926 \mathrm{c}$ \\
Third & $2.2 \pm \mathrm{B}$ & $3.8 \pm \mathrm{C}$ & $3.00 \pm \mathrm{A}$ \\
& $0.270 \mathrm{a}$ & $0.270 \mathrm{~b}$ & $0.926 \mathrm{~b}$ \\
Fourth & $1.00 \pm \mathrm{C}$ & $2.40 \pm \mathrm{D}$ & $2.2 \pm \mathrm{B}$ \\
& $0.246 \mathrm{a}$ & $0.270 \mathrm{~b}$ & $0.447 \mathrm{~b}$ \\
\hline
\end{tabular}

*A-D: values within a column following different letters are significantly different $(\mathrm{P}<0.05)$.

**a-c: values within a raw following different letters are significantly different $(\mathrm{P}<0.05)$.

\section{Acknowledgment}

This study was supported by the College of Veterinary Medicine, Mosul University.

\section{References}

1. Sarker N.,Tsudzuki M., Nishibori M., Yasue H. and Yamamoto Y. Cell mediated and Humeral Immunity and Phagocytic Ability in 
Iraqi Journal of Veterinary Sciences, Vol. 26, Supplement II, 2012 (35-38)

Proceedings of the $6^{\text {th }}$ Scientific Conference, College of Veterinary Medicine, University of Mosul

chicken lines Divergently selected for serum immunoglobulin $\mathrm{M}$ and G levels. Poul sci.2000; 79: 1705-1709.

2. Rahman MM., Bar SM, Giasuddin M., Islam MR., Alam J. and Sil GC.Evaluation of Maternal and Humoral immunity against Newcastle Disease virus in chicken. Int J poult sci.2002; 1(5) : 161-163.

3. Marangon S. and Busan L. The use of vaccination in poultry production. Rev. Sci. Tech. offint. Ep-2.2006; 26(1): 265-274.

4. Hamal KR., Burgess SC., Pevzner IY. an Erf GF. Maternal Antibody Transfer form Dams to their Egg Yolks, Egg Whites, and Chicks in Meat Lines of Chickens. Poult Sci.2006;85: 1364-1372.

5. Youdim. Review - chicken Antibodies IgY. Immune Therapy research laboratory web development Los Angles by ibenet.com.2004.

6. Rauber RH., Flores ML., Pereira CE. and Grigub M. Elisa Evaluation of the Levels of Antibodies Against infectious Bronchitis Virus in Laying Hens Using Egg Yolk as Substrate. Brazilian J Poul Sci.2004; 6(2): 117-119.

7. Shab MSD., Khan SA., Aslam A., Rabbani M., Khan KA. and Rai MF. Effect of Experimental Yolk Sac Infection with Escherichia Coli on Immune status of Broiler Chicks. Pakistan Vet. J.2004; 24(3): 125128.

8. Michael A., Meenatchisundaram S., Parameswari G., Subbraj T., Selvakumaran R. and Ramalingam R.Chicken Egg Yolk antibodies $(\operatorname{IgY})$ as an alternative to mammalian antibodies. Indian $\mathrm{J}$ Sci and Technol.2010; 3(4) : 468-474.

9. Yegani M. and Korver DR. Application of egg yolk antibodies are replacement for antibiotics in poultry. World's poult sci J.2010; 66:2738.

10. Huan H Nguyen, Terrency M Tumpey, Hae Jurg Park and CV Nguyer CV.Prophylactic and Therapeutic Efficacy of Avian Antibodies Against influenza virus HSN1 and H1N1 in Mice. Plos one.2010; 5(4): 1-11.

11. Poovendran P., Kalaigandhi V. and Poogunran E.Use of chicken egg yolk antibody as an alternative to antibiotic treatment for control of ulcer producing Helicobater pylori. Archi Appl Sci Res.2011; 3(4): 493-498.

12. Muhammed K., Rabbi F.,Hussain I. and Hussain T. passive immunization Against Infections Bursal Disease in chicks. Int J Agri \& Biol.2001; 3(4): 413-415.

13. Meenatchisundaram S., Michael A., Subbraj T., Diraviam T. and Shanmugam V.Isolation, Purification and Neutralizing Potential of chicken egg yolk immunoglobulin (IgY) against mastitis causing Escherichia Coli in Diary Cows in Coimbatore District.Int.J.Drug Dev.\&Res.2011; 3(2): 147-153.

14. Wafae AA Comparison Between Immunoglobulins IgY and the vaccine for prevention of infections Bursal disease in chickens Global veterinarian.2011; 6(1): 16-24.

15. Tamilzarasan KB.,Manicavasaka A.,Selvaraja G. and Dorairajan N. Efficacy of Egg Yolk Immunoglobulins (IgY) Against Enteric Pathogens in Poultry.Tamilnaduj. Vet\& Ani Sci.2009; 5(6):264-268.

16. Rudiger S., Staak C., Hendriksen C. and Straughan D. The production of Avian (Egg Yolk) Antibodies IgY. ATLA.1996; 24:925-934.

17. Muhammad K., Arshad R., Sajjad MA.,Akhtar S. and Sheikh MA. Role of passive immunity against Newcastle disease in chickens. Pakistan J. Sci.2001

18. Wil KIE D.C. Non-antibiotic approaches to control pathogens in the gastromtestinal tract of the broiler chicken. Ph.D. Thesis University of Saskatchewan,2006.

19. A.A. Shechan. interference of maternal immunity with immune response of broiler chicks vaccinated with Gumboro vaccine. M.Sc. Thesis Medicine Veterinary Microbiology Mosul, IRAQ.2010; 1-90.

20. Marco RG and Dion H. Duplessis. Eliciting antigen specific egg yolk IgY with Nacked DNA. Drug discovery and genomic technol Bio. Techniques.2001; 31:670-675.

21. Rudiger S.and Coenyaad CH.The production of a vain (Egg) Yolk antibodies : Ig. ATLA.1996; 24:925-934. 